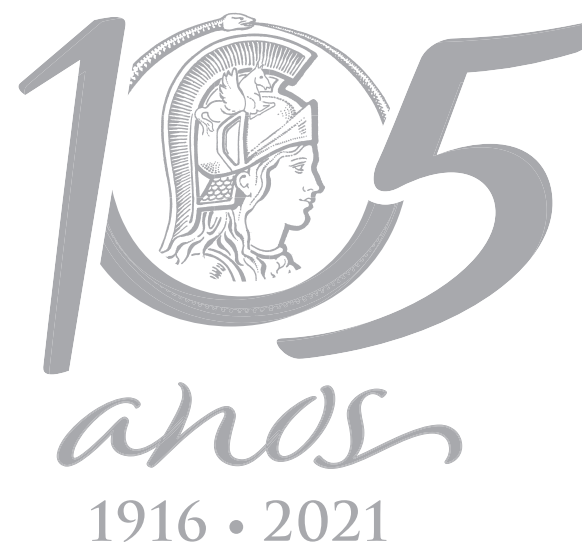

SOCIAL SCIENCES

\title{
Gender Equality in Employment: A View from Kazakhstan
}

\author{
ZHANNA KHAMZINA, YERMEK BURIBAYEV, BINUR TAITORINA \& GULZIRA \\ BAISALOVA
}

\begin{abstract}
Issue under consideration: existing legal resources to support gender equality in the workplace. We systematised the provisions of Kazakhstan labour law, which should guarantee the prohibition of discrimination based on sex. The analysis resulted in five themes: "Characteristics of women's labour", "Analysis of labour laws differentiation", "Evaluation of labour rights discrimination" and "Characteristics of the new labour legislation of the Republic of Kazakhstan", "Characteristics of workers with a special social status". We analysed the essence of the method of differentiation of labour legislation, which affects the establishment of special working conditions for women and workers with family responsibilities. We suggested a correlation between the content of legal norms and the level of guarantees of gender equality in the labour market. The results show that family circumstances, gender equality are factors influencing the formation of labour legislation, state policy in the field of wage labour. The creation of a favourable environment for labour relations of the considered categories of workers should be carried out through labour contracts, acts of the employer, social partnership agreements, collective agreements. However, priority should be given to normative acts of national action. Ensuring gender equality in fact always requires the implementation of special measures by the employer, which must be guaranteed by a coercive state mechanism. At least this thesis is true for the conditions of Kazakhstan, a country with a transition economy, when business does not have high social activity, and state power is in a period of transformation. Importance should be given to the monitoring and implementation of international obligations in the field of ensuring the prohibition of discrimination, the implementation of best practices and standards. The post-Soviet law of Kazakhstan recognises the priority of international law over national law, and this channel should be maximally used to promote the value of gender equality.
\end{abstract}

Key words: discrimination, employment, gender equality, gender, Kazakhstan, women 'slabour.

\section{INTRODUCTION}

Active involvement of women in economic and public life can be defined in terms of factors influencing the dynamics of social policy. The LabourCode ofthe Republic ofKazakhstan defines people with family responsibilities, women as subjects, provided with social and labour guarantees, compensations and allowances, whose legal status bears a differentiation of labour laws Modern law contains rules that enable women during gestation to keep their employment, and during puerperium to maintain their employment without consequence for a child and their upbringing.

Alongside this, the issue of discrimination in the workforce is relevant to the reality of economic relations in Kazakhstan. The most widespread form of discrimination is sexual 
discrimination, as women of any age, with and without children, have far less chances to receive a job offer if their competitor is a man, even if the latter is less qualified or has less experience, employers tend to downsize their workforce or the number of employees by solely making women redundant. A so-called "professional segregation" has emerged in society, and it manifests in a strong division of industries on "male" and "female", "traditional labour of local population" and "migrant labour". "Occupational gender segregation has generally been assumed to be a structure of gender inequality in the labour market; high levels of segregation are equated with high levels of gender inequality in a society" (Blackburn et al. 2000). There has been virtually no shift in industrial gender segregation. Women still compose more than $70 \%$ of employees' healthcare, education and social services, while the representation of women if financial and governmental sectors composes little more than a half. Historically, these sectors are less profitable in comparison to "male sectors", such as construction, the oil and gas sector, extractive industries, transportation.

In 2019, Kazakhstan dropped 12 positions in the gender equality rating compared to 2018. The country took 72nd place among 153 states, and in 2006 Kazakhstan was 32nd. In 2014, the Republic took 43rd position (World Economic Forum 2014), 2015 - 47th (World Economic Forum 2015), in 2017 -52nd place in the ranking (World Economic Forum 2017). Thus, over the past decades, the country's assessment by recognized international experts has been steadily and systematically reduced.

The fall in the rating of Kazakhstan is taking place against the background of outwardly positive changes. In 2009, the Parliament passed two important laws: the Law “On State Guarantees of Equal Rights and Opportunities for Men and Women" and the Law "On Preventionof Domestic
Violence", the state "Strategy for Gender Equality of the Republic of Kazakhstan for2006-2016" was implemented. In 2016, the "Concept of Family and Gender Policy in the Republicof Kazakhstan until 2030" was adopted.

It should be recognized that the situation with equal rights of women and men in Kazakhstan is in deep contradiction that has developed between the formal policy of nondiscrimination, gender asymmetry in state and public life, and the implementation of the constitutional principle of "equal rights and opportunities" of the sexes on the one hand and actual discrimination of women in employment, infringement of their social rights in economic life on the other.

The most discussed topic of gender discrimination is the problem of unequal pay between men and women for the same work and with a comparable level of qualification, low employment of women in leadership positions, a huge gap in the implementation of unpaid homework between the sexes. In the Women's Economic Participation and Opportunity subindex, Kazakhstandropped in the Global Gender Gap Index from 16th place in 2006 to 37th position in 2019. Economic Participation and Opportunity Subindex shows the gap in jobs between the sexes. The fact that women are persistently less present in the labour market than men contributes to the Economic Participation and Opportunity gap. On average about 78\% of adult men (15-64) are in the labour force, while only $55 \%$ of women of the same cohort are actively engaged in the labour market. This means that over $30 \%$ of the global labour force participation gender gap has yet to beclosed. In Kazakhstan, the gap is about 36\%. According to the Economic Participation and Opportunity Subindex, Kazakhstan occupies weak positions in such parameters as "Estimated earned 
income", "Legislators, senior officials and managers", "Labour force participation rate".

The idea of gender equality underlies the construction of welfare states in a number of highly developed countries. Ensuring gender equality in economic opportunities has become one of the "levers of Archimedes", with the help of which countries have achieved impressive successes in a short time in measuring the quality of life of families raising children. We propose to disseminate this experience in Kazakhstan, so that in the process of formation of the welfare state gender equality becomes a real main value. Gender discrimination inhibits economic growth. Due to their influence on the unequal distribution of power between men and women in the family, in the economic sphere and in public life, discriminatory social institutions limit women's economic opportunities (OECD 2014). The absence in Kazakhstan of paid parental leave for children under the age of 3 years, insufficient number of childcare facilities, and a family-oriented policy, along with a gender gap in wages and homework create obstacles for women's full participation in economic relations. The national economy cannot work at full strength, since restrictive and discriminatory factors restrain half the population of Kazakhstan. Waiting for a gender balance to equalize itself is unacceptable. Kazakhstan is losing not only opportunities for economic development, but also the most important value - human capital. Gender equality in employment can be seen as the universal value of international instruments. The principle of prohibition of gender discrimination is inextricably linked with the socio-economic and cultural rights of individuals, widely enshrined in the constitutions of modern states, international covenants on fundamental human rights, ILO conventions, and UN acts, is the Sustainable Development Goal. Kazakhstan has ratified the most important international standards for gender equality, some of which, for example, the Discrimination Employment and Occupation Convention, 1958 (No. 111), were ratified more than 20 years ago. But this does not mean that the standards are applied directly, or Kazakhstanis can take advantage of the proclaimed right, many standards of gender equality have not gone beyond the framework of a legal act, have not become real everyday rights and living conditions.

\section{LITERATURE REVIEW}

Issues of discrimination towards women, people with family responsibilities are relevant today, despite a huge progress in this sphere, positive development of national law systems and universal international standards. Conclusion, expressed in the work of E. Johnstone (1968) half a century ago and observed as valid for current times, asserts that While discrimination and built-inprejudice against women in employment have been lessening in most parts of the world, in law and in practice, many economic, social, and cultural factors and attitudes still place women at a disadvantage in the world of work and restrict their contribution unnecessarily and, in many cases, unfairly. The International Labour Organization (ILO) can help to promote equal rights and opportunities for women and to ensure them the social protection they need in relation to their special role of maternity and motherhood.

Analysis of separate issues of regulatory support of gender equality in workforce is reflected in special scientific studies that focus on employment of migrants (Ruyssen \& Salomone 2018, Platt 2019), balancing work and family responsibilities (Demerouti et al. 2014, Galea et al. 2014, Hilbrecht \& Lero 2014), image 
comparative research into ensuring social and labour rights of women, image image (Hantrias \& Letabiler 2014; image people with family responsibilities Currie 201, Scheubel 2014), application of atypical work (Gialis \& Leontidou 2016, Méda 2016).

This study is based on the scientific studies dedicated to gender inequality in the workplaces of European countries: Laura et al. 1996, Hunter 2003, Tandzegolskiené \& Jurgile 2015, Squires \& Wickham-Jones 2004, Lundqvist 2011, Mihaila 2016. This study was based on the analysis of gender equality in the workplaces of OECD countries (Fortin 2005, Thévenon \& Solaz 2013, Akgunduz \& Plantenga 2013, Barnard 2012) noting that such as the centralized system of production relations, high levels of employment in the public sector compared to the General level of employment and sustained expenditure on active programmes in the labour market, are likely to generate relatively high incomes for women, although not all of these factors contribute to a high level of participation of women in labour markets. No clear evidence was found to support the efficacy of legislative measures in the pursuit of gender equality (Whitehouse 1992).

Academic sources specifically related to Kazakhstan, which we used in preparing the article. Most often, the object of gender studies in Kazakhstan is the national-cultural aspects of the role of women in the development of the society or their role in the economic development of the country, as well as the problems of women's low involvement in political decisionmaking, their negligible representation in the highest echelons of power. A review of theses defended for academic degrees in Kazakhstan for the period from 1992 to 2020 (Kazakhstan 2020, Kodar 2014) allows us to draw the following conclusions. In total, in all branches of science, 25506 theses were defended, of which 50 theses were defended over the problems of the sphere of gender norms, stereotypes, barriers, employment, representation, linguistic gender consciousness. In turn, of them:

4 works - candidate theses in philosophical Sciences and 2 - doctoral;

11 - candidate and 1 - doctoral thesis in Philology;

4 - candidate and 3 - doctoral theses in Sociology;

5 - candidate and 1 - doctoral thesis in Political Science;

5 - candidate theses in Economics;

2 - candidate and 1 doctoral thesis on History;

one study - for the degree of Doctor of Psychological Sciences, one - for the candidate dissertation in Cultural Studies, three for the degree of Candidate of Science in the field of History and Pedagogy;

one PhD thesis in each field - Art History, Gender Psychology, and Sociology.

We would like to emphasize that in Kazakhstan, for the entire period of existence of an independent state, no special dissertation has been prepared in the field of law, devoted to the study of legislation regulating gender equality, the elimination of factors in laws that prevent the liquidation of gender discrimination. The above review shows that today in the field of social sciences, legal research, the topic of gender equality is unpopular. By analysing the sources and implemented projects available on this topic (Kodar 2014), we can conclude that studies on gender equality and the protection of women's rights were more popular from the late nineties to the beginning of the two thousandths. The number of studies and projects on this issue has significantly decreased since the mid-twenties. On the one hand, we believe that this fact is due to systemic changes in legislation in this area. On the other hand, it is 
the implementation of state policy documents aimed at achieving gender balance. The third is the relative success of Kazakhstan in the international gender equality rankings achieved in the early 2000s. However, over the past fifteen years, Kazakhstan's rating has changed dramatically, not for the better, and the country has set itself the ambitious goal of joining the Organization for Economic Cooperation and Development. The OECD countries have accumulated a significant base of good practice on gender equality, which Kazakhstan can rely on. Our study was based on publicly available results of gender-specific analyses of gender conditions in Kazakhstan (McLaughlin 2018, OECD 2017a, b, c, 2018).

\section{CHARACTERISTICS OF WOMEN'S LABOUR}

Despite the fact that the average wage of working women in comparison to men has increased from 62\% in 2006 to $67 \%$ in 2015, the gap between average wage of men and women remains at $33 \%$.

Involvement of women's work in innovative, infrastructural and high-technology projects and programmes is at a very low level. A question of expanding economic opportunity for rural women, who are deprived of access to public, state resources and services, remains relevant. According to national statistics, every third rural woman in Kazakhstan is self-employed and has an income from subsistence farming, part of which goes into personal consumption. Incomes, which also include personal consumption, deprive women of the ability to invest resources into human capital assets in order to return to the real economy.

The Concept is supposed to create the conditions for ensuring equal employment of men and women, notably the following measures will be implemented. Estimates about population's economic activity will be compiled bearing in mind gender specifics of individual regions and production sectors, as well as the poverty monitoring data. Gendersensitive indicators that measure unaccounted domestic labour, informal employment, homebased work, paid domestic labour, will be included in the system of national accounts. Expanding economic opportunity for women will be supported through the facilitation of employment and entrepreneurship, including those economic sectors, which are traditionally managed by men. Taking into account gender aspect, the labour regulation and protection legislation will be enhanced, working conditions will be improved, the possibilities of implementing and expanding flexible forms of employment will be examined. The list of jobs, where utilization of women's labour is prohibited, will be revised and an access to jobs that do not pose danger to women's health by virtue of their automatization, technologization and informatisation will be ensured.

Factors that influence the existence of a sufficiently long period of withdrawal from economic, labour and public life are childbirth and their further support and upbringing, specified circumstances are in the majority of cases "a hindrance" on the way to the realization of their ability for labour, independent economic activity. Alongside the outlined, modern forms of family life allow changes in "traditional" division of responsibilities in the family, transfer of childcare responsibilities unto men or other family members.

On the other hand, the current demographic national policy is directed at stimulating an increase in the birth-rate, including through the provision of social payments, benefits and guarantees. Along with that, integration into work during early puerperium is not a factor that 
hasa positive influence on the development of a child as a future member of society.

Outlined considerations lead to the conclusion about the necessity of finding the optimal way of adhering to everyone's interest in formation of a legislation, realization of national social policy, that takes into account all circumstances and consequences of approved decisions.

\section{ANALYSIS OF LABOUR LAWS DIFFERENTIATION}

The most important feature of labour legislation is its unity and differentiation manifesting in the following. The current combination of labour legislation laws and guarantees, on one hand, expands its scope over all workers employed in the Republic, on all its territory, applicable to thelevel of solidifying common social and labour rights, guarantees and responsibilities. On the otherhand, through various factors like being a minor, specific working conditions, a special ecological status of a territory where the work is conducted, a specific sphere of economic relations or a functioning area of state apparatus, there definitely exist legal rules that establish unique, specific working conditions for affected employees. The design of this labour legislation is expressed by, in one respect, establishing common rights, employees' and employers' responsibilities, an order of contract conclusion, reasons for termination of a contract in labour legislation, and in another, emphasizing rules that consolidate labour regulation of isolated categories of workers.

The differentiation of labour legislation currently exists in labour legislation on the followinggrounds: depending on sex and age characteristics of employees, their health status, family responsibilities;

depending on the nature of labour and work conditions; depending on the territory of labour.

The enhancement of the differentiation is one of the modern trends of labour law development arising from the variety of forms of organizing labour in the society and the need to adjust general rules to certain categories of employees (Golovina 2014).

The foundation of an actual research is provided by the differentiation of labour legislation depending on sex and age characteristics of employees, their health status, family responsibilities.Labour legislation, which consolidates special working conditions for women, people with family responsibilities, was sequentially analysed. Prerequisites for reforming legal regulation of wage labour in Kazakhstan, consequences of implemented reforms were researched. Conclusions about deteriorating status of social and labour rights of people with family responsibilities, women weredrafted.

The analysis was not only based on the research of internal Kazakhstan law, but also on the universal international standards of wage labour, secured in The International Labour Organization (ILO) Conventions and Recommendations.

The study of special labour legislation, which governs labour of women, people with family responsibilities, was conducted from the position of finding a balance between interests of employers, employees and the state in modernizing labour market, protection of social well-beingand stability in society.

An actual research should be perceived as an establishment and a consolidation of a specific scientific level of research into labour laws achieved in Kazakhstan. This article is a 
continuationof an authors' scientific work in the field of wage labour (Mukhamadiyeva et al. 2017, Ibraev et al. 2017, Khamzin et al. 2015).

\section{EVALUATION OF LABOUR RIGHTS DISCRIMINATION}

Discrimination in the workplace can occur on the grounds of sex, age, afflictions, race, nationality, language, property, social and professional status, residence, religious or political beliefs, family or class affiliation, public organization. Despite the approval of numerous international documents ensuring the labour rights, women, people with family responsibilities still suffer from discrimination in the workplace. Only through achieving real, factual gender equality, spreading the awareness about the role and rights of women in society, signing international conventions, governmental and public control over realization of commitments it is possible to solve this problem. Awareness about the need to ensure gender equality, as well as a complex approach through the proper fulfilment of international conventions, agreements and decisions of international organizations using a sophisticated system of mechanisms allows highly-developed countries to ensure social and labour rights of women, people with family responsibilities.

Behind the principle of forbidding discrimination in the workplace is the provision of equalrights and opportunities to workers:

opportunity to obtain employment and be an employee in the organization under any form of ownership;

opportunity to obtain a suitable employment depending on the specialty, qualificationwithout discrimination;

opportunity to demand safe working conditions; opportunity to receive corresponding guarantees, compensations from the employer in case of dismissal; to receive information about employment without discrimination from an official state employment agency;

opportunity to demand the restoration of violated labour rights. The principle of prohibiting discrimination in the workplace covers all subjects of labour laws and is realized in all its institutes.

Based on this research, authors have outlined the following factors that lower the level of labour guarantees for women:

- high level of self-employed population among women;

- restricting employment for women over the age of 40;

- implicit wage discrimination for an equal labour;

- Low level of social allowances and maternity benefits;

- increase in education among women, coupled with a low number of jobs occupied bywomen in high-paid spheres of work;

- absence of guarantees for dismissal due to age, marital status or other discriminatoryreasons;

- higher level of poverty among women in comparison to men.

In our view, establishing additional legislative guarantees in the workplace for people with family responsibilities is aimed at creating equal opportunities for them alongside people, who are not burdened with such responsibilities, while exercising their right for labour, ensuring working conditions that allow them to combine professional and family responsibilities. With these goals in mind, Kazakhstan Labour Code must provide a rule, that obliges employer during recruitment to prioritize people with family responsibilities, 
if they have equal qualifications with other applicants, alongside civilians with quotas for jobs in accordance with established procedures. On the other hand, an employer does not have to suffer significant economic costs when providing social and labour guarantees to people with family responsibilities, for this purpose there should be established tax benefits for employers that utilize the labour of such workers. It is possible to apply similar conditions of tax benefits in the form of a reduction in tax rates for subjects that utilize the labour of handicapped, meaning there should be an incentive for the employer to utilizethe labour of the most socially vulnerable categories of workers. Social responsibility of a businessis an important component when dividing the burden of realizing social policy between a businesscommunity and the state. But the characteristics of social and labour rights depend on them beingsecured and ensured by state mechanism, which compels the government to participate in the implementation of workers' social rights in reality through administrative mechanisms and normative legal regulation.

The main purpose of the legislation is to find an optimal variant between additional guarantees that are established for those who need them and their competitive ability on the job market. It is assumed that factual exclusion of people with family responsibilities from the Labour Code as a category of workers having a special privileged social and labour status does not contribute to a productive employment of these individuals and does not guarantee their non- discrimination in the workplace.

\section{CHARACTERISTICS OF THE NEW LABOUR LEGISLATION OF THE REPUBLIC OF KAZAKHSTAN}

Ensuring gender equality remains to be a sensitive topic in reality of labour relations in Kazakhstan. In 2015-2016 the reform about regulating the sphere of wage labour has been implemented, and the new Labour Code has been adopted. One of the goals of the legislative update was to change the characteristics of normative regulation, reasons for creation, modification, termination of labour relations with one of the most vulnerable categories of workers

- people with family responsibilities, women (the new Labour Code of 2016).

When the new Labour Code was being adopted, one chapter was left out - "Labour of women, people with family responsibilities regulation specifics". The removal of the whole chapter from the Labour Code, which regulated labour of people with the weakest competitive ability in the job market, reflects one possible understanding of labour relations liberalization from the legislator's point of view. Meanwhile, the Labour Code has significantly decreased the level of social dan labour rights of the listed categories of workers regarding the purpose of the guarantees in the previous Kazakhstan Labour Code.

Traditionally, in labour legislation, individuals with family responsibilities are recognized as subjects, whose legal status is differentiation in labour legislation that provides social and labour guarantees, compensations and allowances. Kazakhstan labour legislation began, for the first timesince 2007, incorporating childcare leave upon reaching 3 years age mark at the choice of parents

- mother, father, grandparents, or any other relative or guardian who actually raises a 
child in question. It is worth noting that the specified legal norms are factually inactive in Kazakhstan.

Men rarely use this privilege, therefore there is hardly any legal case involving violations of men'srights that are secured in the Labour Code.

One of legislators' unresolved problem is the absence of a legal definition of workers with family responsibilities: who can be included in this category and regarding whose status working conditions should be differentiated - are still open questions. It is unclear which attributes designate an individual as a worker with family responsibilities. In our view, the following circumstance can designate a worker with family responsibilities: an employee that has a responsibility to educate and nurture a child in accordance with the family or any other legislation (parent, adoptive parent, individual with the rights and responsibilities of a guardian); any other child's relative caregiver in cases directly prescribed by law; a worker with responsibilities regarding their immediate family members who clearly need care or support. The designation of individuals, who raise a child without a mother, can be granted to a father, an individual with the rights and responsibilities of a minor's guardian, if a mother is dead, deprived of her parental rights, limited in her parental rights, declared missing, disabled (partially disabled), cannot raise and support a child for medical reasons, serves a sentence in detention facilities, avoids raising a child or protecting their rights and interests, has refused to collect her child from an educational facility, medical facility, facility providing social services or a similar facility, in other situations. It is assumed that other individuals can be designated as having family responsibilities or raising a child without a mother, taking into consideration concrete circumstances that demonstrate them fulfilling responsibilities (raising a child, carrying for or helping a family member) of public importance.

According to labour legislation, discrimination in the workplace should be understood as a difference, exclusion or a preference aimed at elimination or violation of equal opportunity in realization of labour rights and freedoms or obtainment of any benefits on account of any circumstances that are not connected to professional qualities, besides differences, exclusions, preferences or limitations, established by the Republic of Kazakhstan laws for the corresponding types of employment or that stems from state's special concern about people in need of social and

legal protection. In this regard, it is prohibited to enable disparity in hiring, wages, promotions, individual working conditions, training (professional education and professional instruction), towards women, people with family responsibilities, if it is not connected to employee's professional qualities, their working conditions.

\section{CHARACTERISTICS OF WORKERS WITH A SPECIAL SOCIAL STATUS}

The new labour legislation of Kazakhstan, which took effect in 2016, has significantlydecreased the level of social and labour guarantees for women, children, people with family

responsibilities, regarding forms and methods of workers' rights protection. It actually excludes women with children aged 3 to 7, other individuals who raise children of this age without a mother,and workers who provide care for sick family members that, according to a medical report, need long-term care, from the category of workers with a special social status.

Moreover, limitation of social and labour rights of workers with family responsibilities 
doesnot correspond with the content and level of international commitments, adopted when ratifying the ILO Convention No. 156 (1983) concerning Equal Opportunities and Equal Treatment for Men and Women Workers: Workers with Family Responsibilities (under the Law of the Republic of Kazakhstan of 16 November 2012 No. 50-V). Under universal norms, with which the Republic of the Convention No. 156 Kazakhstan has agreed, applies to men and women workers with family responsibilities in relation to their dependent children where such responsibilities restrict their possibilities of preparing for, entering, participating in or advancing in economic activity; it also applies to men and women workers with responsibilities in relation to other members of their immediate family who clearly need their care or support, where such responsibilities restrict their possibilities of preparing for, entering, participating in or advancing in economic activity (Convention No 156).

Provision of actual equality of treatment and opportunities for men and women workers relies on one of the goals of the state policy where the Convention No. 156 has been ratified offers people with family responsibilities, working or desiring to work, the possibility to exercise their right for it without being subject to discrimination and to combine professional and family responsibilities to the extent possible.

With the purpose of establishing actual equality of treatment and opportunities for men andwomen workers, all measures, corresponding with national conditions and capacities, are taken toensure that:

a) workers with family responsibilities could exercise their right to free choice of employment;

b) their needs concerning working conditions and social security would be taken into account.
According to international act, every state defines "dependent child" and "other member of the immediate family who clearly needs care or support" independently through legislation or anyother method of legal regulation, with the goal of establishing special measures to ensure social and labour rights of workers with family responsibilities. Requirements of the Convention No. 156 may be applied by stages if necessary, account being taken of national conditions. Gradual implementation of measures securing the provisions of the Convention No. 156, a requirement toimplement a respective dedicated state policy, in our view, suggests a progressive development of social and labour rights of workers with family responsibilities by means of pertinent changes in the legislation. However, the level of guarantees in the Labour Code of 2016 is the evidence of regression in relation to the status of the specified participants of labour relations.

Considering the foregoing conclusions, a question arises: how does the regression status of social and labour rights of women, people with family responsibilities, corresponds with the liberalization of the labour legislation as a major dedicated indicator of development and adoption of the Labour Code in 2016?

The new Labour Code was developed as part of a National plan - 100 concrete steps towards the realization of 5 institutional reforms of the Head of State Nursultan Nazarbayev, where step 83: the liberalization of labour relations. Development of the new Labour Code Based on the undertaken informational campaign about adopting and clarifying the Labour Code, its creator viewed liberalization of labour as an enhancement of the role ofacollective contractual regulation of labour relations; expansion of the mechanism of a flexible regulation of wage labour; optimal combination of state and contractual regulation of labour relations. «It is 
suggested that the dominant theme of labour law policy has become the enhancement of the competitiveness of business, which, at its core, requires the facilitation and stabilisation of flexible employment relations» (Collins 2001).

In the author's opinion, liberalization of the labour legislation involves advancing the latter to the real situation and thereby forming prerequisites for its abidance. An emphasis must be placed on creating and expanding the mechanisms of self-regulation on the job market under an appropriate level of state regulation.

Deterioration of status of social and labour rights of people with family responsibilities, women, according to the creator of the new Labour Code, constitutes measures aimed at stimulating the job creation for the specified categories of workers. It is worth noting that the cancellation or limitation of social and labour guarantees for women, children, people with family responsibilities, are advocated for on the grounds that strict mechanisms of ensuring the specified guarantees damage the rights of workers with family responsibilities, women. Employer avoids hiring them. That is why it is currently proposed to significantly reduce social and labour rights ofthese categories of workers.

It is believed that juxtapositions of a presented and widespread position constitute the following. Individuals with family responsibilities, including women, constitute at least 60-70 percent of the total amount of contract workers, as well as of unemployed population. As a result, most workers (men and women) - are workers with family responsibilities that are accountable for their family and children to each other and to society. This large part of the population, which combines family responsibilities and work, must be provided with the ability to exercise their right for free choice of employment without being subject to discrimination. Elimination of the prevalent latent discrimination towards women, people with responsibilities must become the development goal of the labour legislation. The Labour Code has not in any way solved this issue: declaration of prohibiting discrimination, apparently, does not create equal opportunities in exercising rights and freedoms in the workplace.

\section{CONCLUSIONS}

The system of guarantees for women workers, people with family responsibilities, supported by real mechanisms of their legal enforcement, meaning accountability for their violation, was installed into the Labour Code. However, such kind of accountability is absent in some cases. For example, article 6, paragraph 4 of the Labour Code secures the right to appeal to court or another authority in accordance with the law for individuals who believe they have suffered discrimination in the workplace. Nonetheless, the legislation does not determine the procedure of appeal for judicial protection on the basis of discrimination in the workplace, the procedure of shielding from discriminatory actions (inaction) is not legally established, and, moreover, actions of discriminatory nature usually inflict both material and emotional damage. The outlined illustratesthe presence of defects in judicial protection of violated rights procedures exhibiting elements of corruption.

The article 90 of the Labour Code of 5 July 2014 No. 235-V of the Code of Administrative Offences of the Republic of Kazakhstan secures a limited definition of discrimination in the workplace that possesses the elements of an administrative offence. Such offences include: Allowance of discrimination in the workplace expressed as a violation of the right of workers for equal pay for equal labour. Publication of 
information about employment, which contains requirements of discriminatory nature, made by a job centre, an employer or a private employment agency providing labour mediation. All other possible manifestations of discrimination that are not covered by the legal liability.

Flawed enforcement of legal liability for discriminatory offences in the workplace requires further correction, which may motivate the advancement of the institute of social and labour rights of women, people with family responsibilities.

In order to comprehensively create conditions for ensuring equal employment of men and women in Kazakhstan, the following measures are necessary:

- gender-sensitive indicators should be included in the system of national statistical reports, measuring unregistered household work for care, employment in the informal sector, home-based work, domestic work for hire, etc.;

- support is required for women's economic empowerment through employment promotion and entrepreneurship, including in sectors of the economy in which men are traditionally employed;

- considering the gender aspect, improvement of legislation on labour protection and labour protection is in demand, working conditions need to be improved, introduction and expansion of flexible forms of employment are in demand;

- the list of works prohibiting the use of female labour should be revised and women should have access to types of work that do not pose a danger to women's health due to their automation, technologization and informatization;

- trade union organizations should continue to work to protect the labour rights of citizens, including women, involved in innovation, infrastructure and high-tech government projects and programs.

The labour legislation of the Republic of Kazakhstan is defective and must be reformed in order to not only declare, but defend the rights of women in accordance with current reality and fluctuations in the job market.

The study contributes to the research of combating gender discrimination in the job market of Kazakhstan, especially during the employment stage. Discrimination against women on this stage is one of the most prevalent forms of gender inequality.

The study has identified several gaps in the labour legislation. It has been determined how current legislation, which regulates labour relations, complies with the policy of equal rights and

opportunities for men and women. Recommendations were developed, directed at changing legal norms to prevent gender discriminations, which have the purpose to solve existing gender issues in the workplace.

\section{Acknowledgments}

The authors thank anonymous reviewers for important suggestions to the manuscript. Authors acknowledge financial support received from the Ministry of Education and Science of the Republic of Kazakhstan under grant AP09561457.

\section{REFERENCES}

AKGUNDUZ YE \& PLANTENGA J. 2013. Labour market effects of parental leave in Europe. Cambridge J Econ 37: 845-862.

BARNARD C. 2012. EU Employment Law. Oxford: Oxford University Press, 800 p.

BLACKBURN RM, JARMAN J \& BROOKS B. 2000. The puzzle of gender segregation and inequality: A cross-national analysis. Eur Sociol Rev 16: 119-135. 
COLLINS H. 2001. Regulating the employment relation for competitiveness. Ind Law J 30: 17-48.

CONVENTION NO 156. 1983. The Convention on Equal Treatment and Equal Opportunities for Men and Women Workers: Workers image with Family Responsibilities. of August 11. Available on: http://www.ilo.org/wcmsp5/ groups/public/---ed_norm/--- normes/documents/ normativeinstrument/wcms_c156_ru.htm. Accessed: Feb. 10, 2020.

CURRIE S. 2013. Men on the sidelines: The reconciliation of work and family life agenda in the context of crossborder posting. J Soc Welf Fam Law 353: 398-408.

DEMEROUTI E, DERKS D, LIEKE L \& BAKKER AB. 2014. New ways of working: impact on working conditions, work-family balance, and well-being. The impact of ICT on quality of working life: 123-141.

FORTIN NM. 2005. Gender role attitudes and the labourmarket outcomes of women across OECD countries. Oxford Rev Econ Policy 21: 416-438.

GALEA C, HOUKES I \& DE RIJK A. 2014. An insider's point of view: how a system of flexible working hours helps employees to strike a proper balance between work and personal life. Int J Hum Resour Manag 25: 1090-1111.

GIALIS S \& LEONTIDOU L. 2016. Antinomies of flexibilization and atypical employment in Mediterranean Europe: Greek, Italian and Spanish regions during the crisis. Eurn Urban Reg Stud 23: 716-733.

GOLOVINA SY. 2014. Enhancing the Diff erentiation of the Russian Labour Legislation. Russ Law: Theory Pract 2: 86-94.

HILBRECHT M \& LERO DS. 2014. Self-employment and family life: constructing work-life balance when you're 'always on'. Community Work Fam 17: 20-42.

HUNTER L. 2003. Research developments in employment relations and diversity: A british perspective. Asia Pacific JHum Resour 41: 88-100.

HANTRIAS L \& LETABILER MT. 2014. Families and family policies in Europe. Routledge.

IBRAEV ZG, YERKEBAEVA NA, MIRZAKULOVA BA, NAZARKULOVA LT, BURIBAYEV YA \& KHAMZINA ZA. 2017. Social rights, family and child guarantees in the context of the implementation of a new social course in the Republic of Kazakhstan. J Leg Ethical Regul Issues 20: 1-8.

JOHNSTONE E. 1968. Women in economic life: Rights and opportunities. Ann Am Acad Pol Soc Sci 375: 102-114.
KAZAKHSTAN. 2020. National Science Portal of the Republic of Kazakhstan. Available on: http://nauka.kz/ page.php?page_id=107\&lang=1. Accessed: Feb. 10, 2020.

KHAMZIN AS, KHAMZINA ZA \& BURIBAYEV YA. 2015. The Decent Work Programme of Kazakhstan: Social and Labor Rights Protection from an Institutional Aspect of International Law. JE Asia \& Int'l L 8: 539.

KODAR ZM. 2014. Bibliographic index of publications and dissertations on gender issues in the Republic of Kazakhstan. Almaty, 27 p.

LAURA DD, ANNEKE VDH \& JOOP S. 1996. Work-family arrangements and gender inequality in Europe. Women Manag Rev 11(5): 25-35.

LUNDQVIST A. 2011. Family policy paradoxes: Gender equality and labour market regulation in Sweden, 19302010. Policy Press.

MCLAUGHLIN K. 2018. Kazakhstan Country Gender Assessment. Asian Development Bank; Gender and Youth Employment in the Commonwealth of Independent States: Trends and Key Challenges. The Decent Work Technical Support Team and the ILO Office for Eastern Europe and Central Asia. Moscow: ILO.

MÉ DA D. 2016. The future of work the meaning and value of work in Europe. International Labour Organization.

MIHAILA R. 2016. Female labor force participation and gender wage discrimination. J Res Gend Stud 6: 262.

MUKHAMADIYEVA, GN KUSSAINOVA AK \& BAISALOVA GT. 2017. Labour law of the modern Kazakhstan. J Leg Ethical Regul Issues 20: 1-8.

OECD. 2014. Social Institutions and Gender Index (2014) synthesis report. Paris: OECD. Available on: https://www. oecd.org/dev/development-gender/BrochureSIGI2015web.pdf. Accessed: Feb. 10, 2020.

OECD. 2017a. Building Inclusive Labour Markets in Kazakhstan: A Focus on Youth, Older Workers and People with Disabilities. Paris: OECD Publishing. Available on: https://doi.org/10.1787/9789264273023-en. Accessed: Feb. 10, 2020.

OECD. 2017b. Gender Policy Delivery in Kazakhstan, OECD Public Governance Reviews. Paris: OECD Publishing. Available on: https://doi.org/10.1787/9789264280359-en. Accessed: Feb. 10, 2020.

OECD. 2017c. Higher Education in Kazakhstan 2017, Reviews of National Policies for Education. Paris: OECD Publishing. Available on: https://doi.org/10.1787/9789264268531-en. Accessed: Feb. 10, 2020. 
OECD. 2018. SME and Entrepreneurship Policy in Kazakhstan 2018, OECD Studies on SMEs and Entrepreneurship. Paris: OECD Publishing. Available on: https://doi.org/10.1787/9789264301450-en. Accessed: Feb. $10,2020$.

PLATT L. 2019. Understanding inequalities: Stratification and difference. J Wiley \& Sons.

RUYSSEN I \& SALOMONE S. 2018. Female migration: A way out of discrimination?. J Dev Econ 130: 224-241.

SCHEUBEL B. 2014. Does It Pay to Be a Woman?: Labour Demand Effects of Maternity- Related Job Protection and Replacement Incomes (No. 685). DIW Berlin, The German Socio- Economic Panel (SOEP).

SQUIRES J \& WICKHAM-JONES M. 2004. New Labour, gender mainstreaming and the Women and Equality Unit. $\mathrm{Br}$ J Polit Int Relat 6: 81-98.

TANDZEGOLSKIENÉ I \& JURGILE் V. 2015. Work and family reconciliation: issues and policy. I Int Sci Publi: Educ Altern 13: 240-252.

THE LAW OF THE REPUBLIC OF KAZAKHSTAN. 2012. On the ratification of the on Equal Treatment and Equal opportunities for male and female workers: workers with family responsibilities (Convention No. 156). Available on: https://online.zakon.kz/Document/?doc_ id=31292466. Accessed: Feb. 10, 2020.

THÉVENON O \& SOLAZ A. 2013. Labour market effects of parental leave policies in OECD countries, OECD Social, Employment, and Migration Working Papers: 141.

WHITEHOUSE G. 1992. Legislation and labour market gender inequality: an analysis of Available on OECD countries. Work Employ Soc 6: 65-86.

WORLD ECONOMIC FORUM. 2014. The Global Gender Gap Report 2014. Available on: http://reports.weforum.org/ global-gender-gap-report-2014/rankings/?doing_wp_cr on=1579776416.0190749168395996093750. Accessed: Feb. 10, 2020.

WORLD ECONOMIC FORUM. 2015. The Global Gender Gap Report 2015. Available on: http://reports. weforum.org/global-gender-gap-report-2015/ economies/\#economy=KAZ. Accessed: Feb. 10, 2020.

WORLD ECONOMIC FORUM. 2017. Global Gender Gap Report 2017. Available on: http://reports.weforum.org/globalgender-gap-report-2017/dataexplorer/\#economy=KAZ. Accessed: Feb. 10, 2020.

\section{How to cite}

KHAMZINA Z, BURIBAYEV Y, TAITORINA B \& BAISALOVA G. 2021. Gender Equality in Employment: A View from Kazakhstan. An Acad Bras Cienc 93: e20190042. DOI 10.1590/0001-3765202120190042.

Manuscript received on january 29, 2019;

accepted for publication on September 2, 2020

\section{ZHANNA KHAMZINA ${ }^{1}$}

https://orcid.org/0000-0003-0913-2002

\section{YERMEK BURIBAYEV ${ }^{1}$}

https://orcid.org/0000-0003-2631-6372

\section{BINUR TAITORINA ${ }^{1}$}

https://orcid.org/0000-0002-5663-5473

\section{GULZIRA BAISALOVA ${ }^{2}$}

https://orcid.org/0000-0002-8272-3768

${ }^{1}$ Kazakh National Pedagogical University named after Abai, Institute of Law, Department of Law, 050010, Dostyk ave.13, Almaty, Republic of Kazakhstan

${ }^{2}$ Eurasian Law Academy named after D.A. Kunaev, Department of Constitutional, International Law and Customs, 050000,

Kurmangazy ave.107, Almaty, Republic of Kazakhstan

\section{Correspondence to: Zhanna Khamzina}

E-mail:292803@mail.ru

\section{Author contributions}

Leading author, Zh. Khamzina, managed and was responsible for all stages of the research, design and concept of the research project, development, writing and reviewing of the manuscript, in direct partnership with co-author Y. Buribayev. Co-authors B. Taitorina and G. Baisalova participated in writing and revising the final version of the manuscript. All the team that integrated the study maintained harmony and commitment in all the activities that gave rise to this scientific manuscript.

\section{(cc) BY}

